\title{
A Eurasian or a European Future for Post-Soviet Georgia's Economic Development: Which is better?
}

\author{
Vladimer Papava \\ Professor of Economics, Faculty of Economics and Business \\ Ivane Javakhishvili Tbilisi State University. Tbilisi, Georgia
}

\begin{abstract}
The paper analyze the economic models of the well-known Eurasianist doctrine of Russian imperial thinking and the Eurasian Economic Union (EAEU). In the modern era of globalization, an alliance of countriesuras on the basis of the Eurasianist economic model is impossible to establish. The newly established EAEU rests on a redistribution mechanism for oil and gas revenues, whereby Russia deliberately relinquishes a part of its due gains in favor of other member-states in order to not only induce economic interest to remain within the Union, but also to maintain and enhance its political influence via this economic output. Western economic sanctions imposed against Russia as a countermeasure to the invasion and annexation of Crimea and the military and political support provided to the breakaway regions of Eastern Ukraine, as well as the retaliatory anti-sanctions levied by Russia against the West, have demonstrated the fragility and instability of the EAEU. A comparison of the EU with the EAEU does not favor the later. Although attaining membership of the EAEU is much easier than that of the $E U$, the negative aspects described above ensure that this option holds no appeal for post-Soviet Georgia.
\end{abstract}

Keywords: Eurasian Economic Union, EU, Eurasianism, economic sanctions, postSoviet Georgia

\section{INTRODUCTION}

A new Russian-Kazakh regional project (for example, Nurgaliyeva, 2016), known as the Eurasian Economic Union (EAEU), commenced operation in 2015. Specifically, this means that, as of January 1, 2015, integrated economic processes between Belarus, Kazakhstan and Russia are governed by the Treaty on the Eurasian Economic Union. As of January 2, 2015 Armenia acceded to the EAEU, followed by Kyrgyzstan on May 21.

It is noteworthy that the concept of the expediency of such a union was put forward as early as 1994 by Kazakhstan's President Nursultan Nazarbayev (Alpysbaeva, 2014; Gleason, 2001, 2002; Mostafa, 2013).

The Russian version of regional integration of post-Soviet countries nominally is based on the economy (for example, Galiakberov \& Abdullin, 2014).

Despite the fact that Georgia has long made its choice in favor of Europe (and Euro-Atlantic institutions) (for example, Rondeli, 2001), talks on Georgia's rapprochement with Russia have recently reignited. On the one hand, this interest in rapprochement was sparked by the uncertainty arising in Georgian-Russian relations (Rondeli, 2013), on the other - by the establishment and apparent launching of the EAEU (for example, Mendkovich, 2015; Vinokurov, 2016). 
In order to respond to the question on whether or not the EAEU will persuade Georgia to alter its European course, it is crucial to review the essence of the EAEU itself. It must also be stressed that ample literature is available on the European Union (EU) and the road towards its membership, while the EAEU is a much newer construct and intensive research into its workings is virtually underway at this moment.

Following the 2011 announcement by the Russian President regarding the establishment of the EAEU (for example, Bryanski, 2011; Putin, 2011), some politicians and experts (for example, Sevim, 2013) have perceived the event as the ultimate victory of Eurasianism in Russia. So, the research of the problem has to be started from the analysis of the economic foundations of Eurasianism.

\section{ON THE ECONOMIC FOUNDATION OF EURASIANISM}

Eurasianism, established in the 1920s, is one of the most powerful doctrines of the Russian geopolitical school, and is aimed at the institution of Russia's distinguished historical and cultural role in Eurasia (for example, Laruelle, 2008). Public interest in Russia developed around this theory in the 1990s following the collapse of the Soviet Union, when Russia began to seek an auspicious anti-Western, imperial, and integrative doctrine (Ismailov \& Papava, 2010; Papava, 2013) and Eurasianism was undergoing a significant modernization. It should be said that the so-called myths (Tolz, 1998) and narratives (Aktürk, 2006, p. 23) about the homeland were largely encouraged by the talks about revising the Russian Federation state borders, which are much more popular in the intellectual and political communities of Russia and among the Russian public than is believed in Western academic writings (Tolz, 1998, p. 294). This is perfectly natural if we keep in mind the post-imperial nostalgia popular in Russian society (Gaidar, 2007, pp. ix-xiv). Imperial order, the imperial body, and the imperial mind are the three components of Russia's imperial syndrome structure (Pain, 2008). Of these components, the imperial body, that is, the country's territory, is the most inert. At the same time, in fact, its territory, as the receptacle of natural, labor, financial, and other resources, acts as the main resource, the expansion or at least containment of which is the main task of the imperial state (Pain, 2008).

Eurasianists pay particular attention to the teachings of the so-called 'hetero-orthodox' economists who regard the economy as a derivative of culture and for whom historical, cultural-civilizational, spatial, and national factors are of prime importance in determining the nature of the economy (Dugin, 2002b, p. 627).

According to the Eurasianist economic model (Dugin, 2002a), the market principle should not undermine ideocracy, or the ability of ideological fundamentals to dominate social and political life. As a result, the task of the Eurasian economy is to preserve and develop all the economic systems reflecting the cultural-historical path of the individual nations living in the Eurasian State (Dugin, 2004c, p. 286). In other words, the multi-vector nature of Eurasianism should be formed on the basis of: 1. Government control in strategic areas (that is, the land of Eurasia, its rivers, lakes, seas, minerals and their production and primary processing enterprises, armed forces, the military-industrial complex, the financial institution issuing Eurasian currency, pension funds, transportation routes, and the energy industry should be owned by the government); 2. A free market in small and medium production, trade, and services; 3 . Diverse forms of collective management (that is, cooperatives, joint-stock enterprises, and so on, permitted in industry, construction, banking, credit, and stock exchange spheres, medical services, education, culture, and so on) (Dugin, 2004c, p. 288). 
For Eurasianists, the market and private ownership belong to a pragmatically allowable and pragmatically advantageous realm, based on which they acknowledge "society with a market," rather than "market economy." Consequently, the objective of an Eurasianist economy is to maintain and develop all economic systems reflecting the cultural and historical path of the specific peoples living in Eurasia. Eurasianists prefer the "principle of possession" to the "principle of ownership." In the first case, proprietors are to abide by their social responsibilities and focus on the welfare goals of society, rendering them accountable to society and the government. Additionally, the principle of possession envisions that the government should encourage domestic entrepreneurship and carry out a paternalistic policy, simultaneously applying mechanisms of tariff and non-tariff protectionism.

It is difficult to envisage how the economic model of Eurasianism can be implemented in practice in a country given the modern process of globalization underway worldwide. It is noteworthy that Russian economists have also recognized the incompatibility of the concepts of Eurasianism with the reality of the modern world (for example, Greenberg, 2013, p. 10).

According to Eurasianists, the Eurasian economic community will establish a so-called independent "fourth zone" based on the principles discussed above, which will not only differ substantially from other gigantic economic zones - such as America, Europe and the Pacific but also oppose them (Dugin, 2002b). The principled difference between the fourth zone and the others is also reflected in the post-Soviet state's problematic choice of its path - either toward Europe or toward Eurasia (for example, Zhalilo, 2003).

When looking at the main views of Eurasianists, a question arises: what is more important to them, those principles discussed above on the basis of which the Eurasian State should be built, or the restoration of a Russian empire at any price? This formulation is primarily provoked by the fact that despite their disparagement of Marxism, Eurasianists welcomed the establishment of a Soviet structure that extended Russian territory (for example, Arutiunov, 2000; Dugin, 2002a, p. 629, 2004b; Utkin, 2000b). In this context the Soviet Union is qualified as the Soviet Eurasian Empire (Hauner, 1994). While also disparaging liberal-capitalist orthodoxy, the current leaders of Eurasianism, although rather skeptical about Anatoli Chubais' idea of creating a so-called Liberal Empire (Chubais, 2003) ended up welcoming this idea, according to which Russia could and should restore its economic influence (for example, Kissinger, 2002, p. 76) by means of economic expansion (for example, Crane, Peterson \& Oliker, 2005) throughout the post-Soviet expanse. They did this by actively describing this project of restoring the Russian empire as liberal Eurasianism (Dugin, 2004a, pp. 99-103).

Chubais' idea of a Liberal Empire was particularly popular in 1998-2005 (Simons, 2008, pp. 7081). Of great significance is also the interconnection between Energy Dependence and Political Independence in the Russian policy towards the post-Soviet space: an increase in the first seems to cause a decline in the second (Smith, 2004, pp. 5-8). It is no accident that, along with the formation of a Liberal Empire, the purposeful movement toward creating an Energy Empire is of particular importance to Russia (Hill, 2004). This is largely based on Putin's myth of Russia as an "energy superpower" (Shevtsova, 2007, pp. 133, 194). As a result, Moscow's energy policy is promoting the conception of New Economic Imperialism, which applies not only to the outside world, but also to Russia itself, to its domestic economy (Goldman, 2008a, 2008 b, pp. 172-176). It is worth regarding Russia's energy strategy in the European vector in this context too (Bugajski, 2008, pp. 73-80).

It is noteworthy that, given the governance regime of Belarus, the country's economy comes closest to exhibiting the features of the economic model of Eurasianism (such as "society with a 
market" and state ownership as a guarantor of achieving social welfare), while more or less successful market reforms have already been carried out in Armenia and Kazakhstan in particular, and at the initial stage of the post-Soviet era in Kyrgyzstan and Russia. Using the different wording Belarus is a Marxist-Leninist state, with a social market economic structure (Bell, \& Bell, 2015. p. 155). Such appraisal of the situation in Belarus is not far from the Eurasianist vision.

The principal goal of the EAEU at the current stage is to deepen the trade and economic integration of its member countries, which is in no way linked with the economic model of Eurasianism, even on a theoretical level. Moreover, this corollary applies not only to economic models, but to Eurasianism and the Eurasian Union in general (Laruelle, 2015).

\section{ON THE POLITICAL ECONOMY OF THE MODERN STATE OF THE EAEU}

A key economic motif that facilitates the integration process of the EAEU is a redistribution mechanism for revenues from oil and gas. Specifically, no export duty is imposed within the EAEU; consequently, the price of a given resource is reduced by the amount of the export duty in contrast with the global price for said resource, which leads to domestic production subsidies. Export duties are collected only when commodities exit the borders of the EAEU, at which point some of the revenues to be received by Russia would be redistributed to the benefit of other member countries. As oil and gas comprise the main export product for Russia, it is the redistribution of the revenues received from these commodities that is a key economic motive for integration.

Even though the scheme on which the EAEU is based is economically unprofitable for Russia, it is a scheme that secures Moscow's imperial ambition of the gradual reanimation of the Soviet Union in its modernized form. This approach by Moscow towards the EAEU is not at all surprising, given the fact that it is on the basis of the consumption of energy resources (Hill, 2004) that Russia has set course towards geopolitics (Appel \& Gelman, 2015), rather than towards economic development.

Today, it is noteworthy that global prices on raw materials, especially on energy resources, are exhibiting a clear downward trend. Thus, the effectiveness of the redistribution mechanism outlined above is reduced.

As early as a few years ago, Russia considered the possibility of entering agreements on Free Economic Zones (FEZ) with certain countries (such as New Zealand (for example, Ballingall, 2010), Vietnam (for example, RT, 2013b), Israel (for example, Keinon, 2013), India (for example, Dikshit, 2013) and the USA (for example, RT, 2013a)) and regional associations (for example, ASEAN (for example, Lisovolik, 2010), EFTA (for example, "EFTA," 2013) and the EU (for example, Maliszewska, Jarocinska \& Scasny, 2010)). On May 29, 2015 such an agreement was signed with Vietnam (for example, Reuters, 2015), while negotiations with the remaining countries and regional associations have either been suspended or not yet initiated, due largely to political reasons.

According to the forecasts of Russian economists (covering the three founding members of the EAEU - Belarus, Kazakhstan and Russia), the conclusion of FEZ agreements, both in the short and long term, will result in economic benefits for the EAEU as a whole, as well as for Russia and Kazakhstan; Belarus will experience losses if the other party to a FEZ agreement is an economically developed country (Knobel, 2015, pp. 95-96). Considering that all members of the EAEU have the veto power, in order to prevent Belarus from exercising its veto power in 
case a FEZ agreement is signed, it is necessary to develop an internal redistribution mechanism benefiting Belarus.

As a result of Russian annexation of Crimea and the armed conflict in Eastern Ukraine, as of the spring of 2014, the US (subsequently joined by other countries) imposed economic sanctions against Russia (for example, Koenig, 2015). This posed a new challenge to the EAEU, as the sanctions do not apply to its other member states.

As of August 2014, Moscow imposed so-called anti-sanctions (for example, McHugh, 2015), thereby counteracting the existing sanctions against Russia and banning the import of food products from the US, the EU, Australia, Norway and Canada.

Given that the sanctions are only imposed against Russia and do not apply to other member counties of the EAEU, the latter have not joined the anti-sanctions as imposed by Russia. Therefore, the goods banned by Moscow may still enter the territory of Russia from other EAEU member countries. This possibility is not ruled out by the common customs territory of the EAEU which includes all of its member countries.

The experience of imposing countersanctions has demonstrated that it is primarily Russia that has incurred losses.

It is clear that the existing situation fundamentally opposes the principle of the integrity of the EAEU's common customs territory. In effect, the imposition of countersanctions has prompted the division of the territory into two areas: that of Russia and that of the other EAEU member countries.

The probability that the other member countries of the EAEU will voluntarily join Moscow's anti-sanctions is low, as this would be economically unreasonable for these countries. If Moscow applies any mechanism of pressure to influence these countries, this will further undermine the already fragile foundations of the EAEU and raise questions about its future.

Moreover, it is notable that, if Moscow should use any form of pressure against the existing member states, this would scare away other countries that Moscow may consider potential new members of the EAEU.

Because of its political ambitions, it can almost be guaranteed that Moscow will not forfeit the countersanctions until the sanctions imposed against Russia are lifted.

In general Russia is not fundamentally different from the West, and the "...national character will not prevent Russia from becoming a truly democratic society someday" (Shiller, 2016), but in current days Moscow's imperialist ambitions prevail over the common sense (Papava, 2014, pp. 7-8).

Thus, it is now less likely that the existing system of "sanctions and anti-sanctions" will be altered at the expense of any compromise on the part of Moscow.

As a conclusion, it can be stated that the realization of the economic model of Eurasianism in the modern global world is a utopian concept, while the economic model of the EAEU in itself is not only unstable, but also inadequate. This has become most apparent against the background of the sanctions imposed against Russia and the anti-sanctions introduced by Moscow (Papava, 2015a). This conclusion is reinforced by the fact that, in 2016, due to 
increasing pressure stemming from the sanctions, on the one hand, and the continuing downward trend in global prices on energy resources on the other, Russia's economic turmoil is likely to deteriorate further (Dynkin \& Baranovskii, Eds., 2015).

\section{WHAT IS BETTER FOR GEORGIA'S ECONOMY: EUROPEAN OR EURASIAN CHOICE}

When discussing which course is more suitable for Georgia, the European or Eurasian, one must take into account all possible factors, such as historical experience and prospects for development under Eurasian cooperation and European integration (for example, Obydenkova, 2011), the economic and security interest of the EU in Eurasia (Laruelle, 2016), as well as post-Soviet Georgia's experience of relations with EU and Russia (Kuchins, Mankoff, \& Backes, 2016), and of its economic reforms (Papava, 2012). The economic component is one of the most significant constituent parts of any interstate association, and calls for a particular examination.

It will not suffice to focus solely on the fact that Georgia was forcibly pulled into the USSR, and moreover, that it must not return to its ranks, modernized though they may be. It is essential to analyze the dangers that the country's future may hold. This, in turn, calls for a more or less detailed examination of a range of issues.

First and foremost, the essential disparities between the EU and the EAEU must be emphasized. These disparities are rather substantial, and each distinction is discussed in detail below.

Purpose of Establishment. The EU was initially set up as an economic union, in other words, a union with the aim to promote the economic development of its member states. Although the EAEU contains the term "economic" in its title, this union, as noted above, is not so much a means of economic development as it is a tool that Moscow employs to maintain and increase its political influence on the member states of the EAEU via an economic mechanism (namely, redistribution of revenues not in Russia's favor).

Current Economic Status. Despite the fact that some countries in the Eurozone are experiencing a crisis, the EU in its entirety (with the partial exception of several Eastern European countries) is an association of states with developed economies, while the EAEU comprises of post-Soviet countries complete with deficient market institutions and a technological lag (for example, Papava, 2010). While the leading EU countries are postindustrial (in the classic sense of the term), the countries comprising the EAEU (as well as other post-Soviet countries, with the exception of the Baltic States) are post-Soviet postindustrial (Gorodezky, 2013). This is not so much a result of the development, or lack thereof, of a high-quality service sector in these countries, as it is of the backwardness of industrial production (Papava, 2015b). Consequently, while the EU is principally an alliance of economically developed countries, the EAEU is an association of countries with clear-cut institutional and technological backwardness.

Corruption Level. According to the results of Transparency International's Corruption Perceptions Index of 2016 (TI, 2017), Denmark was the least corrupt country in the EU, ranked first among 176 countries, while the most corrupt state in the EU was Bulgaria, ranked 75th among the world's best. In contrast, the highest-ranking country in the EAEU is Belarus, which is 79th on the global scale, while the lowest-ranking country is Kyrgyzstan, sharing the 136th position. For comparison, Georgia ranks 44th, which renders it more in compliance with the EU standard (the closest EU-member states are Spain at 41, and Latvia at the same 44). 
The Complexity of Membership. A country's ambition does not solely suffice for it to become a member of the EU. It is imperative that an applicant country meet certain standards recognized by Brussels in areas such as democratic institutions, human rights, freedom of speech and expression, and market economy. Accordingly, only after an applicant country has met European standards in all of the fields listed above is the issue of EU enlargement to include the applicant placed on the agenda. In order to encourage rapprochement with the EU, Brussels has adopted special formats of cooperation - for instance, the European Neighborhood Policy (ENP) instrument and the Eastern Partnership (EaP). Georgia is a participant of both formats (for example, Gogolashvili, 2009). It is through the application of the EaP framework that Georgia has managed to successfully traverse the rather difficult path towards the achievement of the Deep and Comprehensive Free Trade Area (DCFTA) agreement (for example, Kakulia, 2014), as well as the EU Association Agreement (CG, 2015).

Unlike the EU, the EAEU has virtually no complex preconditions for membership (for example, EEK, 2014). On the contrary, Moscow's political aim is to expand the union in order to increase its political influence on member-states via economic leverage.

If the distinctive elements between the EU and the EAEU are summed up, it can be concluded that Georgia can more easily attain membership of the latter than the former. However, this evokes the logical question of why Georgia, as a country with a more or less EU-level standard of corruption, should enter the much more (approximately doubly) corrupt EAEU, which lags behind the EU in institutional and technological terms, and simultaneously serves Moscow's political objective to strengthen Russian control over the countries in its alliance via economic leverage. It is evident that the answer to the question will not be in favor of EAEU membership.

Moreover, it must also be emphasized that the so-called "commensurability barrier" for the EAEU is much more critical than for the EU. The renowned Russian economist, Ruslan Greenberg brings this issue into focus when comparing the Commonwealth of Independent States (CIS) with the EU (Greenberg, 2013, p. 9). In particular, an alliance of countries is streamlined and the alliance itself has a higher chance of success when the commensurables (sizes) of the member countries is more or less comparable. When an alliance of countries is formed, the states concerned should make a decision on the areas where they are ready to relinquish part of their sovereignty in favor of the supranational governing bodies of the association. When the commensurability of the countries is more or less analogous, reaching consensus on this matter is easier than when one country and its economy are several times larger in size than those of all the other constituents of the union put together. In this case, the largest country finds it difficult to imagine how it can be expected to yield a share of its sovereignty equivalent to that of much smaller states. As a result, this large country attempts to relinquish far less of its state sovereignty than it obligates the other smaller member states to surrender, thereby maintaining a dominant position in the association.

One of the reasons of the EU's success is also the fact that it consolidates relatively large and simultaneously commensurably more or less homogeneous countries, such as Germany, Great Britain, Italy and France, and relatively small but commensurably comparable countries, such as Belgium, Ireland, the Netherlands, etc.

According to Greenberg, the "commensurability barrier" for the CIS was rather high, since the Russian economy accounted for 67-70\% of the entire economy of the CIS (Greenberg, 2013, p. 9). This barrier is even further increased when considering the EAEU, as Russia's share constitutes over $82 \%$ of the entire economy of the Union (EEK, 2015). 
Thus, the "commensurability barrier" is also a testament to the fact that the EAEU does not have a high chance for successful development. Then the question regarding whether or not Georgia should become a member of this Union becomes even less likely to secure a positive response.

EU membership cannot be a target for Georgia, rather, it is a means to achieve the objective by which the country's population can live in dignity, democratic institutions are sufficiently developed, human rights are protected to the highest possible extent, the freedom of speech and expression is no longer restricted, and market economy is developed to a level conducive to developing the economic fundamentals necessary for a dignified quality of life. In order to achieve these objectives, Georgia should adopt and establish EU standards, which will ultimately bring the country closer to the EU.

\section{CONCLUSION}

The economic foundation of the well-known Eurasianist doctrine of Russian imperial thinking is not "market economy," but rather "society with a market." For the Eurasianists, the economy should be subordinated to the idea of the Eurasian State, Eurasian civilization, and Eurasian culture. For them, the market principle should not threaten the foundations of ideocracy, that is, those ideal principles that rule public and political life. The multi-vector nature of Eurasianism should be formed on the basis of government control in strategic areas, a free market in small and medium production, trade, and the service sphere, as well as diverse forms of collective management.

In the modern era of globalization, an alliance of countries on the basis of the Eurasianist economic model is close to impossible to establish, as, even in the post-Soviet countries where authoritarian rule has been instituted (with a few exceptions), preference is given to market economy rather than "society with a market."

The newly established EAEU rests on a redistribution mechanism for oil and gas revenues, whereby Russia deliberately relinquishes a part of its due gains in favor of other memberstates in order to not only induce economic interest to remain within the Union, but also to maintain and enhance its political influence via this economic output.

Western economic sanctions imposed against Russia as a countermeasure to the invasion and annexation of Crimea and the military and political support provided to the breakaway regions of Eastern Ukraine, as well as the retaliatory anti-sanctions levied by Russia against the West, have demonstrated the fragility and instability of the EAEU. This is primarily reflected by the fact that the EAEU member-states are not and cannot be economically congruent with Russia.

A comparison of the EU with the EAEU does not favor the later, as, in contrast with the former organization, the EAEU is far more corrupt, with underdeveloped market institutions, and an unequivocal delay in technological development.

Moreover, an impeding factor to the development of the EAEU is the so-called "commensurability barrier," which prevents Russia from yielding a measure of its sovereignty to the Union's supranational governance bodies identical to that which it desires the other member-states to relinquish.

Although attaining membership of the EAEU is much easier than that of the EU, the negative aspects described above ensure that this option holds no appeal for Georgia. 


\section{References}

Aktürk, Ş., 2006. Reflections on Central Eurasian Model: A Foundation Reply to Barfield on the Historiography of Ethno-Nationalisms. Central Eurasian Studies Review, 5(2), 19-25.

Alpysbaeva, Zh. 2014. Nursultan Nazarbaev: OT idei evrazii'skogo sojuza k perspektivam evrazii'skoi' integratsii [Nursultan Nazarbaev: From the Idea of the Eurasian Union to the Perspectives of Eurasian Integration]. Zakon.kz, May 30. http://www.zakon.kz/4628189-nursultan-nazarbaev-ot-idei.html.

Appel, H., and Gelman, V., 2015. Revising Russia's Economic Model: The Shift from Development to Geopolitics. PONARS Eurasia Policy Memo, No. 397, November. http://www.ponarseurasia.org/sites/default/files/policymemos-pdf/Pepm397_Appel-Gelman_Nov2015.pdf.

Arutjunov, S. A., 2000. Rossija mezhdu Zapadom i Vostokom [Russia between the West and the East]. Diskussionny' Klub. Krugly' STOL No. 3 [Discussion Club. Round Table No. 3]. http://nnmoiseev.ru/st0023.htm.

Ballingall, J., 2010. New Zealand-Russia FTA: Another BRIIC in the Wall. NZIER Insight, November 15. http://nzier.org.nz/static/media/filer_public/7d/c5/7dc503d6-dda7-44b5-b9f1-

2e00d613ca6e/nzier_insight_21_-_russia_fta.pdf.

Bell, H., and Bell, R., 2015. Post-Crisis Belarus: Marxism and the Lender of Last Resort. Journal of Eurasian Studies, 6(2), 153-160.

Bryanski, G., 2011. Russia’s Putin says wants to build 'Eurasian Union'. Reuters, October 3.

http://www.reuters.com/article/us-russia-putin-eurasian-idUSTRE7926ZD20111003.

Bugajski, J., 2008. Expanding Eurasia: Russia's European Ambitions. Washington, DC: The CSIS Press.

CG, 2015. Georgia, EU Sign Association Agreement. Civil.Ge, June, 27.

http://www.civil.ge/eng/article.php?id=27417.

Chubais, A., 2003. Missia Rossii v XXI veke [Russia's Mission in the 21st Century]. Nezavisimaia gazeta [Independent Newspaper], October 01. http://www.ng.ru/ideas/2003-10-01/1_mission.html.

Crane, K., Peterson D. J., and Oliker O., 2005. Russian Investment in the Commonwealth of Independent States. Eurasian Geography and Economics, 46(6), 404-444.

Dikshit, S., 2013 it's Time for Free Trade Pact with Russia, Says India. The Hindu, April 2.

http://www.thehindu.com/news/national/its-time-for-free-trade-pact-with-russia-saysindia/article4570802.ece.

Dugin, A. G., 2002a. Ekonomicheskie aspekty neoevraziystva [The Economic Aspects of Neo-Eurasianism]. In A. Dugin (Ed.) Osnovy Evraziystva [The Fundamental Principles of Eurasianism], 626-637. Moscow: ArktogeiaTsentr.

Dugin, A. G., 2002b. Ekonomika: chetvertaia zona [The Economy: The Fourth Zone]. In A. Dugin (Ed.) Osnovy Evraziystva [The Fundamental Principles of Eurasianism], 657-661. Moscow: Arktogeia-Tsentr.

Dugin, A., 2004a. Evraziyskaia missiia Nursultana Nazarbaeva [Nursultan Nazarbaev's Eurasian Mission]. St. Petersburg: Evraziia.

Dugin, A., 2004b. Petr Savitskiy ideolog Velikoy Evrazii [“Pyotr Savitskiy Ideologist of a Great Eurasia”]. FINIS MUNDI, No. 12, Arktogeia filosofskiy portal [Arktogeia Philosophical Portal]. http://www.arcto.ru/article/1110.

Dugin, A., 2004c. Proekt “Evraziia” [The “Eurasia” Project]. Moscow: Eksmo, Yauza.

Dynkin, A. A., and Baranovskii V. G. (Eds.) (2015). Rossija i mir: 2016. Ekonomika i vneshnjaja politika. Ezhegodmyi prognoz [Russia and the World: 2016. Annual Forecast: Economy and Foreign Policy]. Moscow, IMEMO RAN. http://www.imemo.ru/files/File/ru/publ/2015/2015_024.pdf.

EEK, 2014. Evrazii'skii' ekonomicheskii' sojuz. Voprosy i otvety. Tsifry i fakty [Eurasian Economic Union. Questions and Answers. Figures and Facts]. (2014). Moscow: Evrazii'skaja ekonomicheskaja komissija [Eurasian Economic Commission]. http://www.eurasiancommission.org/ru/Documents/eaes_voposy_otvety.pdf.

EEK, 2015. Ob osnovnykh sotsial'no-ekonomicheskikh pokazateljakh gosudarstv-chlenov Evraziiskogo ekonomicheskogo sojuza [On the Main Social and Economic Indicators of the Member States of the Eurasian Economic Union]. Evraziiskaja ekonomicheskaja komissija [Eurasian Economic Commission]. January-November. 
http://www.eurasiancommission.org/ru/act/integr_i_makroec/dep_stat/econstat/Documents/Indicators201511 .pdf.

EFTA, 2013. EFTA States Pursue Free Trade Negotiations with Russia, Belarus and Kazakhstan. EFTA, April 12. http://www.efta.int/free-trade/free-trade-news/2013-04-11-efta-rubeka-8th-rnd-fta-neg.

Gaidar, Y., 2007. Collapse of an Empire. Lessons for Modern Russia. Washington, DC: Brookings Institution Press.

Galiakberov, A., and Abdullin, A., 2014. Theory and Practice of Regional Integration Based on the EurAsEC Model (Russian Point of View). Journal of Eurasian Studies, 5(2), 116-121.

Gleason, G., 2001. Kazakhstan's Nazarbayev Heads New EEC Organization. EurasiaNet, June 17. http://www.eurasianet.org/departments/business/articles/eav061801.shtml.

Gleason, G., 2002. Kazakhstan Positioned as Locomotive of Eurasian Integration. EurasiaNet, February 10. http://www.eurasianet.org/departments/business/articles/eav021102.shtml.

Gogolashvili, K., 2009. The EU and Georgia: The Choice is in the Context. In Mkrtchyan T., Huseynov T., and Gogolashvili K. The European Union and the South Caucasus. Three Perspectives on the Future of the European Project from the Caucasus. Europe in Dialogue 2009/01, 90-127. Gütersloh: Bertelsmann Stift. http://eeas.europa.eu/delegations/georgia/documents/virtual_library/30_xcms_bst_dms_en.pdf.

Goldman, M. I., 2008a. Moscow's New Economic Imperialism. Current History, 107(711), October, 322-329.

Goldman, M. I., 2008b. Petrostate: Putin, Power, and the New Russia. New York: Oxford University Press.

Gorodezky, A. E., 2013. Antikrizisnoe regulirivanie i modeli postkommunisticheskogo razvitija Rossii [Crisis Management and the Post-Crisis Development Model for Russia]. Ekonomika Ukrainy [Economy of the Ukraine], 5, 66-74.

Greenberg, R., 2013. Kontury novoiy ekonomiki i shansy evraziyskoiy integratsii [Contours of New Economy and Chances of the Eurasian Integration]. Ekonomisti [Economist], 6, 6-11.

Hauner, M. L., 1994. The Disintegration of the Soviet Eurasian Empire: An Ongoing Debate. In M. Mesbahi (Ed.) Central Asia and the Caucasus after the Soviet Union, 209-233. Gainesville: University Press of Florida.

Hill, F., 2004. Energy Empire: Oil, Gas and Russia's Revival. London: The Foreign Policy Centre. http://fpc.org.uk/fsblob/307.pdf.

Ismailov, E., and Papava, V., 2010. Rethinking Central Eurasia. Washington, DC: Johns Hopkins University-SAIS, Stockholm: Institute for Security and Development Policy.

http://www.silkroadstudies.org/resources/pdf/Monographs/2010_MONO_Ismailov-Papava_Rethinking-CentralEurasia.pdf.

Kakulia, M., 2014. Georgia's Experiences on Developing Trade and Trade Policy Relations with the European Union. East European Studies, 5, 137-160. http://vki.hu/files/download_772.html.

Keinon, H., 2013. Israel and Russia to Negotiate Free-Trade Agreement. The Jerusalem Post, December 10. http://www.jpost.com/Diplomacy-and-Politics/Israel-and-Russia-to-negotiate-free-trade-agreement-334603.

Kissinger, H., 2002. Does America Need a Foreign Policy? Toward a Diplomacy for the Twenty-First Century. London: The Free Press.

Knobel, A., 2015. Evraziiskiy ekonomicheskiy sojuz: perspektivy pazvitija i vozmozhnye prepijatstvija [Eurasian Economic Union: Prospects and Challenges for Development]. Voprosy ekonomiki [Economic issues], 3, 87-108.

Koenig, P., 2015. Russia, The Circus of Economic Sanctions Continues: Washington and Brussels Against Moscow. Global Research, December 24. http://www.globalresearch.ca/russia-the-circus-of-economic-sanctionscontinues-washington-and-brussels-against-moscow/5497752.

Kuchins, A., Mankoff J., and Backes, O., 2016. Georgia in a Reconnecting Eurasia. Foreign Economic and Security Interests. Washington, DC: Center for Strategic \& International Studies. https://csisprod.s3.amazonaws.com/s3fs-public/publication/160429_Kuchins_GeorgiaReconnectingEurasia_Web.pdf.

Laruelle, M., 2008. Russian Eurasianism: An Ideology of Empire. Washington, DC: Woodrow Wilson Center Press. 
Laruelle, M., 2015. Eurasia, Eurasianism, Eurasian Union: Terminological Gaps and Overlaps. PONARS Eurasia Policy Memo, No. 366, July. http://www.ponarseurasia.org/sites/default/files/policy-memospdf/Pepm366_Laruelle_July2015.pdf.

Laruelle, M., 2016. The European Union in a Reconnecting Eurasia. Foreign Economic and Security Interests. Washington, DC: Center for Strategic \& International Studies. https://csis-prod.s3.amazonaws.com/s3fspublic/publication/160428_Laruelle_EUReconnectingEurasia_Web.pdf.

Lisovolik, Y., 2010. Is a Russia-ASEAN Free Trade Area of Any Use? International Affairs, Special Issue. https://interaffairs.ru/i/pdf_asean/11.pdf.

Maliszewska, M., Jarocinska, E., and Scasny, M., 2010. Modeling Economic, Social and Environmental Implications of a Free Trade Agreement between the European Union and the Russian Federation. CASE Network Reports, No. 93/2010. http://www.case-research.eu/upload/publikacja_plik/29994065_CNR_93.pdf.

McHugh, J., 2015. Russian Sanctions: Putin Signs Decree Ordering All Western Imported Food 'Destroyed.' International Business Times, July 30. http://www.ibtimes.com/russian-sanctions-putin-signs-decree-orderingall-western-imported-food-destroyed-2031380.

Mendkovich, N., 2015. Na puti k evraziiskomu ekonomicheskomu chudu. Rossiya i integratsiya na postsovetskom prostranstve [On the way to the Eurasian Economic Miracle. Russia and Integration at the Post-Soviet Space]. Moscow: Algoritm.

Mostafa, G., 2013. The Concept of 'Eurasia': Kazakhstan's Eurasian Policy and its Implications. Journal of Eurasian Studies, 4(2), 160-170.

Nurgaliyeva, L., 2016. Kazakhstan's Economic Soft Balancing Policy vis-à-vis Russia: From the Eurasian Union to the Economic Cooperation with Turkey. Journal of Eurasian Studies, 7(1), 92-105.

Obydenkova, A., 2011. Comparative Regionalism: Eurasian Cooperation and European Integration. The Case for Neofunctionalism? Journal of Eurasian Studies, 2(2), 87-102.

Pain, E., 2008. Liberaly sdaiutsia bez boia [The Liberals Surrender without a Fight]. Nezavisimaia gazeta, February 1. http://www.ng.ru/ideas/2008-02-01/11_theway.html.

Papava, V., 2010. The Economic Challenges of the Black Sea Region: the Global Financial Crisis and Energy Sector Cooperation. Southeast European and Black Sea Studies, 10(3), 361-371.

Papava, V., 2012. Economic Reforms in Post-Communist Georgia: Twenty Years After. New York: Nova Science Publishers.

Papava, V., 2013. The Eurasianism of Russian Anti-Westernism and the Concept of 'Central Caucaso-Asia'. Russian Politics and Law, 51(6), 45-86.

Papava, V., 2014. Old or New Cold War? CICERO Foundation Great Debate Paper, No. 14/07, October. http://www.cicerofoundation.org/lectures/Papava_Old_or_\%20New_Cold_Warx.pdf.

Papava, V., 2015a. Economic Models of Eurasianism and the Eurasian Union: Why the Future is Not Optimistic. The Central Asia-Caucasus Analyst, October 29. http://cacianalyst.org/publications/analyticalarticles/item/13296.

Papava, V., 2015b. Necroeconomics of Post-Soviet Post-Industrialism and the Model of Economic Development of Georgia and Russia. Journal of Business and Economics, 6(5), 976-983.

http://www.academicstar.us/UploadFile/Picture/2015-7/20157313847837.pdf.

Putin, V., 2011. A New Integration Project for Eurasia: The Future in the Making. Permanent Mission of the Russian Federation to the European Union, October 3. http://www.russianmission.eu/en/news/article-primeminister-vladimir-putin-new-integration-project-eurasia-future-making-izvestia-3-.

Reuters, 2015. Vietnam Signs Free Trade Agreement with Russian-Led Economic Union. The Moscow Times, May 29. http://www.themoscowtimes.com/business/article/vietnam-signs-free-trade-agreement-with-russian-ledeconomic-union/522691.html.

Rondeli, A., 2001. The Choice of Independent Georgia. In G. Chufrin (Ed.), the Security of the Caspian Sea Region, 195-211. New York: Oxford University Press. 
Papava, V. (2017). A Eurasian or a European Future for Post-Soviet Georgia's Economic Development: Which is better? Archives of Business Research, 5(1), 159-170.

Rondeli, A., 2013. Georgia-Russia: From Negative to Positive Uncertainty. Expert Opinion No. 3. Tbilisi: Georgian Foundation for Strategic and International Studies (GFSIS). http://gfsis.org/media/download/library/articles/Expert_Opinion_ENG_3.pdf.

RT, 2013a. Russia Looks to Boost Bilateral Trade with US. RT Question More, December 12. https://www.rt.com/business/russia-usa-trade-shuvalov-111/.

RT, 2013b. 'Special Comrades' Russia and Vietnam to Double Trade by 2015. RT Question More, November 12. https://www.rt.com/business/russia-vietnam-trade-agreement-580/.

Sevim T. V., 2013. Eurasian Union: A Utopia, a Dream or a Coming Reality? Eurasian Journal of Business and Economics, 6(12), 43-62. http://www.ejbe.org/EJBE2013Vol06No12p043-SEVIM.pdf.

Shevtsova, L., 2007. Russia Lost in Transition: The Yeltsin and Putin Legacies. Washington, DC: Carnegie Endowment for International Peace.

Shiller, R. J., 2016. Is Russia's National Character Authoritarian? Project Syndicate, March 14. https://www.project-syndicate.org/commentary/is-russian-national-character-authoritarian-by-robert-j-shiller-2016-03.

Simons, Jr. T. W., 2008. Eurasia's New Frontiers: Young States, Old Societies, Open Futures. Ithaca: Cornell University Press.

Smith, K. C., 2004. Russian Energy Politics in the Baltics, Poland, and Ukraine. A New Stealth Imperialism? Washington, DC: The CSIS Press.

TI, 2017. Corruption Perceptions Index 2016: Results. Transparancy International. http://www.transparency.org/news/feature/corruption_perceptions_index_2016?utm_medium=email\&utm_cam paign=CPI\%202016\%20General\%20Mailer\&utm_content=CPI\%202016\%20General\%20Mailer+Version+A+CID_ 310d39acff23636ebb54eda828e1e89d\&utm_source=Email\%20marketing\%20software\&utm_term=SEE\%20RES ULTS\#table.

Tolz, V., 1998. Conflicting "Homeland Myths" and Nation-State Building in Postcommunist Russia. Slavic Review, 57(2), 267-294.

Utkin, A. I., 2000. Evraziyskaia tochka zreniia [The Eurasianist Viewpoint]. Diskussionny Klub. Krugly STOL No. 3 [Discussion Club. Round Table No. 3]. http://nnmoiseev.ru/st0022.htm.

Vinokurov, E., 2016. Evraziiskyi ekonomicheskyi soiuz bez emotsyi [Eurasian Economic Union: A Sober Look]. Voprosy ekonomiki [Economic issues], 12, 43-60.

Zhalilo, Y., 2003. Ukraine: Eurasian Integration or European Choice? Central Asia and the Caucasus, 6(24), 159167. 